\title{
Protein Transport Protein Sec23B
}

National Cancer Institute

\section{Source}

National Cancer Institute. Protein Transport Protein Sec23B. NCI Thesaurus. Code C97935.

Protein transport protein Sec23B (767 aa, $\sim 86 \mathrm{kDa}$ ) is encoded by the human SEC23B gene. This protein plays a role in the transport of protein from the endoplasmic reticulum to the Golgi. 